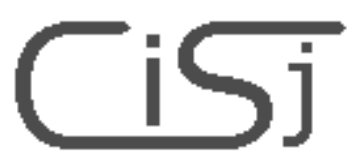

computing@tanet.edu.te.ua www.tanet.edu.te.ua/computing
ISSN 1727-6209

International Scientific Journal of Computing

\title{
МЕТОДИ ТА ВИСОКОПРОДУКТИВНІ ПАРАЛЕЛЬНІ СИСТЕМИ ДЛЯ ОБРОБКИ ТА РОЗПІЗНАВАННЯ ЗОБРАЖЕНЬ У РЕАЛЬНОМУ ЧАСІ
}

\author{
В.В.Грицик ${ }^{1}$, О.М. Березький ${ }^{2}$ \\ 1) Державний науково-дослідний інститут інформаційної інфраструктури \\ Національної академії наук України \\ та державного комітету зв' язку та інформатизації України \\ вул. Тролейбусна 11 , Львів \\ vvhrytsyk@polynet.lviv.ua \\ 2) Кафедра інформаційно-обчислювальних систем і управління \\ Тернопільська академія народного господарства, \\ пл. Перемоги, 3, Тернопіль, 46004 \\ ob@tanet.edu.te.ua
}

\begin{abstract}
Анотація: В статті розглянуті основні проблеми, які виникають під час обробки і розпізнавання зображень у реальному часі та запропоновані методи і високопродуктивні паралельні засоби засоби для їх вирішення.
\end{abstract}

Ключові слова: обробка зображень, розпізнавання зображень, синтез зображень, паралельна обробка інформачїі.

\section{1. ОСНОВНІ ПРОБЛЕМИ}

Сучасні і прогнозовані вимоги до теорії i практики методів і систем відбору, передачі, обробки великої кількості інформації, що швидко надходить, до сприйняття, розпізнавання і класифікації складних зображень обумовлюються необхідністю розв'язання в комплексі багатьох важливих проблем інформаційних технологій та обчислювальної техніки. У зв'язку з цим, вимагається проведення комплексних досліджень для створення нових теоретичних i практичних принципів, що задовольняють новим вимогам систем реального часу (проблема забезпечення реального часу). При цьому особливу увагу слід звернуги на досягнення високої інформаційної ефективності та достовірності одержання правильного результату в умовах інтенсивної дії завад (проблема забезпечення високої інформаційної ефективності, достовірності отримання правильного результату в умовах інтенсивної дії завад, надійності, гнучкості, готовності та живучості систем реального часу). Крім цього важливим $є$ пошук принципово нових методів і технічних засобів, що дозволяють розв'язувати задачі розпізнавання i класифікації складних зображень. Значну кількість задач обробки багатовимірних сигналів вдалось розв'язати лише завдяки швидкому розвитку цифрових технологій.
Далі розглядаються випадки, коли зображення є складними за своєю структурою, а число інформативних ознак, що характеризують зображення, - великим (проблема оптимального відбору інформативних ознак та опису складних зображень). У ряді випадків при вирішенні задач попередньої обробки i розпізнавання не існує конструктивних алгоритмів і технічних засобів для розпізнавання та класифікації складних зображень, недостатня швидкодія сучасних універсальних ЕОМ для забезпечення дієздатності системи в реальному часі. Поряд 3 цим відомо, що з погляду технічних можливостей існує теоретична межа швидкодії елементної бази, що визначається швидкістю світла Тому пошуки нових можливостей повинні проводитися в галузі структурного аналізу алгоритмів та технічної реалізації за допомогою високопродуктивних систем обробки інформації (проблема розробки високоефективних алгоритмів обробки інформаціі). Основним структурним підходом є подальший розвиток принципу паралелізму. При цьому паралелізм обробки інформації передбачає різні форми і методи розпаралелювання (проблема розпаралелювання алгоритмів). Отже, для забезпечення реального часу функціонування систем необхідно розробляти нові підходи до побудови технічних систем, що забезпечують високопродуктивну обробку інформації на всіх 
етапах сприйняття, попередньої обробки та розпізнавання складних зображень.

Обсяг інформації, що використовується в керуючих системах, досягає $10^{10}-10^{14}$ байт. Це зумовлює подалыше збільшення продуктивності обробки інформації. Одним із підходів до підвищення продуктивності систем обробки інформації $є$ розвиток нової архітектури таких систем, що забезпечує нові можливості, побудови алгоритмів розпізнавання та класифікації в системах реального часу. Розроблювані системи реального часу (спецпроцесори, проблемноорієнтовані структури) можуть використовуватись при керуванні апаратами на небезпечних для життя операціях, при роботах на дуже віддалених об'єктах, у системах зондування і т.п. Такі системи призначені для пошуку, обробки, розпізнавання та класифікації великої кількості інформації, що швидко надходить, про складні об'єкти в космічних, земних і морських глибинах. У зв'язку з цим особливо важливе значення мають фундаментальні та прикладні дослідження з розробки нових технічних засобів для розпізнавання та класифікації складних зображень (проблема синтезу та проектування високопродуктивних спецпроцесорів i проблемнооріснтованих систем, системних середовищ, нейроподібних і систолічних структур).

У ряді випадків при розв'язанні задач розпізнавання в реальному часі $\epsilon$ принципові труднощі через відсутність конструктивних методів і відповідної технічної і елементної бази для реалізації як в стаціонарних умовах, так і в застосуванні на рухомих платформах (проблема проектування i синтезу принципово нової елементної бази).

Для опису, розпізнавання i класифікації складних зображень в реальному часі нами розроблений і запропонований структурний підхід, що базується, 3 одного боку, на використанні ієрархічного принципу побудови складного зображення i, 3 другого - на можливості глибокого розпаралелювання алгоритму обробки інформації. Це дозволяє сформулювати принципово новий перспективний напрямок фундаментальних і прикладних досліджень 3 розробки спеціалізованих надшвидких обчислювальних пристроїв, а також проблемно-орієнтованих систем, нейроподібних структур, системних середовищ паралельної дії та їх математичного забезпечення, що орієнтоване на досягнення високої продуктивності, достовірності, надійності, гнучкості, живучості і готовності всіх складових систем реального часу. При цьому необхідно звернути увагу на попереднє опрацювання одержуваного зображення.

Далі покажемо, що спеціалізовані паралельні обчислювальні пристрої, а також проблемноорієнтовані системи, структури, середовища реалізують процеси попередньої обробки складних ситуацій і алгоритмів розпізнавання та класифікації в реальному часі, забезпечуючи при цьому високу ефективність і якість всіх етапів роботи системи реального часу. Відзначимо принципово важливі моменти при такому підході до розробки методів i засобів обробки i розпізнавання складних зображень у системах реального часу.

Цей підхід дає можливість описувати велику множину складних зображень за допомогою невеликої множини непохідних елементів і відповідних правил [15].

Кожне зображення розділяється на складові на основі апріорі заданих операцій, що дозволяє розпаралелювати алгоритм визначення непохідних елементів.

Використання ієрархічної i рекурсивної природи алгоритмів попередньої обробки інформації i розпізнавання дає можливість провести реалізацію паралельних та рекурсивних систем надвисокої продуктивності, забезпечуючи при цьому оптимальну відповідність алгоритмів обробки і розпізнавання систем, що реалізують ці алгоритми.

Змінність структури високопродуктивних пристроїв обробки інформації в пошукових системах дозволяє організувати структури найадекватніші розв'язуваним задачам розпізнавання складних зображень i досягти заданого рівня продуктивності, а також заданих показників достовірності, надійності, гнучкості, живучості та готовності.

Конструктивна однорідність сприяє високій технологічності виробництва і зниженню його вартості при реалізації обчислювальних паралельних структур в системах реального часу.

При розробці надвисокопродуктивних спеціалізованих паралельних пристроїв, націлених на розв'язання задач обробки i розпізнавання складних зображень, потрібно апріорі визначити ті основні властивості внутрішнього паралелізму алгоритмів, закономірностям яких підпорядковується структура системи обробки інформації. Визначення основних класів обчислювальних алгоритмів, що припускають розпаралелювання на заданому рівні та дозволяють реалізацію обчислювального алгоритму на заданий час, $є$ фундаментальною проблемою, від розв'язання якої багато в чому залежить успішна i цілеспрямована розробка високопродуктивних структур паралельної дії в системах обробки i розпізнавання (проблема визначення класів алгоритмів, що допускають розпаралелювання). Це дозволяє оптимально наблизити структуру задачі обробки i розпізнавання зображень до структури розроб- 
лювальної системи. Така відповідність може бути цілком досягнута лише тоді, коли відомі основні принципи побудови класів алгоритмів, що дозволяють розпаралелювання. тобто закони що визначають внутрішню структуру високоефективних паралельних алгоритмів сприйняття, обробки, розпізнавання i класифікації складних зображень. На сучасному етапі розвитку інформаційних технологій і систем такий підхід нам видається найперспективнішим структурним напрямком розробки інформаційних систем. Він забезпечує високі технічні і якісні показники.

\section{2. МАТЕМАТИЧНА МОДЕЛЬ СИСТЕМИ ПОПЕРЕДНЬОЇ ОБРОБКИ, РОЗПІЗНАВАННЯ I КЛАСИФІКАЦІЇ СКЛАДНИХ ЗОБРАЖЕНЬ В РЕАЛЬНОМУ ЧАСІ}

Розглядається математична модель системи попередньої обробки, розпізнавання i класифікації складних зображень в реальному часі. Ця модель включає попередню обробку, розпізнавання і класифікацію зображень, видачу керуючих сигналів.

Попередня обробка зображень передбачає кодування, фільтрацію, відновлення і поліпшення якості зображення. Розпізнавання i класифікація передбачають використання узагальнених показників для віднесення зображень до визначеного класу i видачу відповідних керуючих впливів. Особлива увага приділена збільшенню точності, надійності, живучості і готовності системи в цілому, а також забезпеченню реального часу i високої достовірності одержання правильного результату.

Запропоновано підхід до реалізації обчислювального процесу (ОП) на обчислювальній системі (ОС), структурі, середовищі або спеціалізованому багатопроцесорному пристрої паралельної дії (СБППД). При цьому ОП задається за допомогою операторів $\mathrm{O}_{1}, \mathrm{O}_{2}, \mathrm{O}_{3}, \ldots, \mathrm{O}_{\mathrm{r}}$, а ОС складається з Пs, процесорів, s > r. Всі процесори мають доступ до загальної пам'яті. Виділяються такі умови реалізації ОП на ОС:

Режим реального часу.

Процеси реалізуються дуже часто.

Процес реалізується рідко і з ним не пов'язані жорсткі тимчасові обмеження.

Виходячи 3 теоретико-множинного підходу, досліджується модель пошуку. Введено поняття пошукової ситуації $\mathrm{C}=\left\{\mathrm{C}_{1}, \mathrm{C}_{2}, \mathrm{C}_{3}, \ldots, \mathrm{C}_{\mathrm{n}}\right\}$ i зображень об'єктів $\mathrm{R}=\left\{\mathrm{R}_{1}, \mathrm{R}_{2}, \mathrm{R}_{3}, \ldots, \mathrm{R}_{\mathrm{n}}\right\}$.

Визначимо поняття відношення виявлення О̃: $\mathrm{R}_{\mathrm{i}} \tilde{\mathrm{O}} \mathrm{R}_{\mathrm{j}}$, якщо $\mathrm{R}_{\mathrm{i}}$, де $\mathrm{R}_{\mathrm{i}} \in \check{\mathrm{R}}$, - множина зображень, $\tilde{\mathrm{O}}$ $\epsilon$ відношенням еквівалентності.
При цьому, 1. $[\mathrm{R}]=\left\{\mathrm{R}_{\mathrm{i}} / \mathrm{R}_{\mathrm{j}} \tilde{\mathrm{O}}_{\mathrm{i}}\right\}=\check{\mathrm{R}} ; \mathrm{R}_{\mathrm{i}}, \mathrm{R}_{\mathrm{j}}, \in \check{\mathrm{R}}$. 2. Відношення О人 розбиває всю множину зображень на дві множини Ŕ i R - множина зображень, в яких немає об'єкта. Побудуємо навчальне відношення пошуку в момент $t-\Pi, \subset \mathrm{Cx \textrm {R }}$, що обчислює відношення пошуку $\Pi_{t}^{M} \subseteq R \times M \quad$ i навчальне відношення пошуку $\Pi_{t M} \subseteq C \times \tilde{C}$, де $\Pi_{t M}$ - бінарне відношення з С в множину $\tilde{C}$, що складається лише із $\tilde{C}_{1} i \widetilde{C}_{2}$, де $\tilde{C}_{1}$ - клас ситуації, у якому є зображення об'єкта, $\tilde{C}_{2}$ - клас ситуації, в якому відсутне зображення. Вирішальне відношення пошуку $\Pi_{t}^{M}$ дає можливість проводити лише виявлення і воно залежить від даних навчання $\Pi_{t}$ і $\Pi_{t M}$. Пару $\left\{\Pi_{t}, \Pi_{t M}\right\}$ назвемо даними навчання при пошуку зображення. Після одержання нової множини ситуацій $C_{t}$ визначається $\Pi_{z} \subseteq C_{z} \times R$ і задача пошуку полягає в знаходженні правила, що дозволяє віднести оптимальним, у деякому розумінні чином, елементи $C_{z}$ в класи $\tilde{C}_{1}$ або $\tilde{C}_{2}$, базуючись на $\left\{\Pi_{t}, \Pi_{t M}\right\}$. Досліджені можливості безпомилкової роботи системи пошуку для різноманітних пошукових ситуацій. Отримано умови найкращого вирішального відношення для пошуку. При цьому мінімізується число помилок, пов'язаних із неправильним віднесенням ситуацій до класів. Ці моделі найперспективніші при розробці високоефективних систем пошуку.

Виходячи 3 теоретико-множинного підходу запропонована математична модель високопродуктивних систем паралельної обробки інформації, що забезпечують вирішення задач попередньої обробки інформації, а також попередньої обробки, розпізнавання і класифікації : складних зображень в реальному часі.

Визначення 2.1. Системою обробки інформації будемо називати відношення на непорожніх множинах $S \subset \times\left\{V_{i} ; i \in I_{n}\right\}$, де $\mathrm{V}_{\mathrm{i}}$ об'єкт системи; $X=\subset \times\left\{V_{i} ; i \in I_{x}\right\} \quad$ - вхід системи, $Y=\times\left\{V_{i} ; i \in I_{y}\right\}$ вихід системи, $\mathrm{I}_{\mathrm{H}}, \mathrm{I}_{x} \mathrm{I}_{y}-$ множина індексів.

Розглядаються системи $S \subset\left\{X, C_{0}, Y\right\}$, де $\mathrm{C}_{0}$ - канал, що здійснює перетворення інформації. Досліджені основні властивості систем; розглянугі функціональні системи [1,2].

Визначення 2.2. Функціональні системи $\mathrm{S}_{1}, \mathrm{~S}_{2}, \ldots, \mathrm{S}_{\mathrm{n}}$ будемо називати інформаційно взаємонезалежними, якщо 


$$
X_{1} \cap\left\{Y_{2}, Y_{3}, \ldots, Y_{n}\right\}=\mathscr{O}, X_{2} \cap\left\{Y_{1}, Y_{3}, \ldots, Y_{n}\right\}=\mathscr{O}, \ldots, X_{n} \cap\left\{Y_{1}, Y_{3}, \ldots, Y_{n-1}\right\}=\mathscr{O}
$$

системи $\mathrm{S}_{1}, \mathrm{~S}_{2}, \ldots, \mathrm{S}_{\mathrm{n}}$ допускають паралельну обробку інформації в часі.

На цій основі можна синтезувати різні моделі паралельних обчислювальних систем [1-7].

\section{3. ПОКАЗНИКИ ОЦІНКИ ЯКОСТІ I ЕФЕКТИВНОСТІ СИСТЕМ ПАРАЛЕЛЬНОЇ ОБРОБКИ ІНФОРМАЦІЇ}

Важливу роль при оцінці ефективності різних систем обробки інформації при розпізнаванні складних зображень має вибір відповідних показників оцінки. Нами досліджені основні показники якості й ефективності систем обробки інформації і запропонований узагальнений інформаційний показник оцінки ефективності методів і систем паралельної обробки інформації в системах реального часу з використанням інформаційного підходу [8].

Важливою проблемою при технічній реалізації систем реального часу $є$ забезпечення високої достовірності і надійності в умовах стабільної роботи елементів або дії перешкод. Досліджено і запропоновано методи обробки інформації, а також отримані конструктивні оцінки інформаційних показників для забезпечення високої достовірності і надійності $[5,8]$. При цьому розглядається імовірнісна модель паралельного ОС. Вхід (вихід) паралельного ОС характеризується парою, $\left\{X_{i S}, P_{S}^{i}\right\}\left\{\left\{\tilde{Y}_{j}, P_{j}\right\}\right)$, де $X_{i S}\left(\tilde{Y}_{j}\right)$ - множина даних на вході (виході) $P_{S}^{i}\left(P_{j}\right)$ - можливість 3 якою вибираються дані 3 $X_{i S}\left(\tilde{Y}_{j}\right), i=\overline{1, n}, s=\overline{1, k}_{i}, \sum_{i} P_{S}^{i}=1, \sum_{j} P_{j}=1$

Кожний набір даних $x_{t}^{i}=\left(x_{1 t}^{i}, x_{2 t}^{i}, \ldots, x_{k_{i}}^{i}\right)$ визначає єдиний вихід $y_{i t+1}$; кожна підсистема $\mathrm{S}_{\mathrm{i}}$, реалізовує деяку функцію $y_{i t+1}=f_{i}\left(x_{1 t}^{i}, x_{2 t}^{i}, \ldots, x_{k_{i}}^{i}\right)$ або процес обробки інформації. Охарактеризуємо поведінку такої підсистеми множиною умовних ймовірностей $\left\|P\left(y_{i t+1} / x_{t}^{i}\right)=P_{i j}\right\|, \partial e i, j=\overline{1, n}, \quad$ таких, що $P_{i j}=\left\{\begin{array}{l}1, y_{i t+1}=f_{1}\left(x_{1 t}^{i}, x_{2 t}^{i}, \ldots, x_{k_{i}}^{i}\right) \\ 0, y_{i t+1} \neq f_{1}\left(x_{1 t}^{i}, x_{2 t}^{i}, \ldots, x_{k_{i} t}^{i}\right)\end{array}\right.$

Введемо інформаційні показники системи. Середня кількість інформації, що пов'язана 3 входами $x_{1 t}^{i}, x_{2 t}^{i}, \ldots, x_{k_{i} t}^{i}$ і виходами $\hat{Y}_{\mathrm{j}}$ відповідно рівні $H\left(x_{i}\right)=\sum_{s=1} H\left(x_{i s}\right), H_{j}$, а середня кількість інформації, отриманої на виході, дорівнює

$I=\left(H\left(X_{i}\right)-H\left(X_{i} / \tilde{Y}_{j}\right)\right),\left(I=H\left(\tilde{Y}_{j}-H\left(\tilde{Y}_{j} / X_{i}\right)\right)\right)$

Обробка інформації має місце, якщо $H\left(X_{i}\right)>H\left(\tilde{Y}_{j}\right)\left(\right.$ або $H\left(X_{i} / \tilde{Y}_{j}\right)>0$ ). Нами запропонована узагальнена модель паралельної ОС обробки інформації в умовах надійної роботи іiі елементів або дії перешкод. 3 цією метою вводиться додатково канал 3 шумом і нульовою затримкою в часі, тобто паралельної ОС, представленої у вигляді послідовного з'єднання ідеальної паралельної ОС і каналу з шумом. При цьому на виході ОС угворюються дані $з$ деякої множини Z. Поведінка такої системи характеризується матрицею умовних ймовірностей

$$
\left\|P\left(z_{j t+1} / x_{t}^{i}\right)\right\|=\left\|P_{i j}^{(z)}\right\|, j=\overline{i, n}, z_{j t+1} \in Z .
$$

Ці ймовірності задовольняють умовам $P\left(z_{i t+1} / x_{t}^{i}\right)=P\left(z_{i t+1} / \tilde{x}_{t}^{i}\right), \forall z_{j t+1} \in z_{j} \quad$ якщо

$$
f_{i}\left(x_{1 t}^{i}, x_{2 t}^{i}, \ldots, x_{k_{i} t}^{i}\right)=\left(\tilde{x}_{1 t}^{i}, \tilde{x}_{2 t}^{i}, \ldots, \tilde{x}_{k_{i}}^{i}\right) i P\left(z_{j t+1} / x_{i t}\right)=\sum_{s}^{n} P\left(z_{j t+1} / y_{s t+1}\right) .
$$

Середня кількість інформації на виході в результаті паралельної обробки в умовах дії шуму дорівнює середній кількості інформації на вході мінус середня кількість інформації, що втрачена через дію шуму або використана на забезпечення надійної роботи елементів.

Однією 3 важливих задач ОС паралельної обробки інформації $\epsilon$ досягнення високої достовірності обробки інформації в складних умовах експлуатації. Як показник достовірності паралельної обробки інформації обрана величина ймовірності одержання правильного результату на виході Pnp. Для порівняльної оцінки ефективності і якості методів і систем паралельної обробки інформації запропоновані узагальнені показники

$$
\eta=\frac{I}{V} i v=\frac{H\left(X_{i} / Y_{s}\right)+H\left(Y_{s} / Z_{j}\right)}{H\left(X_{i}\right)}, \quad \text { які } \epsilon
$$

функціями всіх основних параметрів ОС і розглядаються для заданого значення достовірності [8]. За допомогою цих показників можна оцінити наскільки ефективно використовується канал i 
порівнювати ОС як за потенційними можливостями поза конкретними умовами їх застосування, так і за ефективністю використання в заданих умовах. Відношення v краще описує якість відтворення результату, ніж міра ймовірності помилки, тому що враховує значення похибки. Досліджена можливість підвищення достовірності й ефективності обробки в паралельних ОС в умовах надійної роботи елементів і дії перешкод. 3 метою дослідження можливостей реалізації заданого ОП із заданою достовірністю одержання правильного результату побудована відповідна модель ОС. У цій моделі вводиться трійка $\mathrm{M}^{\mathrm{f}_{\mathrm{i}}}=\left(\mathrm{K}_{\mathrm{i}}, \mathrm{S}_{\mathrm{i}}, \mathrm{D}_{\mathrm{i}}\right)$, яка визначається як метод обробки інформації для реалізації функції $f_{i}$, а пара $\mathrm{M}_{\mathrm{i}}=\left(\mathrm{K}_{\mathrm{i}}, \mathrm{D}_{\mathrm{i}}\right)$ визначає засіб кодування і декодування інформації, $i=1, q$. При цьому передбачається, що $\mathrm{K}_{\mathrm{i}}, \mathrm{S}_{\mathrm{i}}, \mathrm{D}_{\mathrm{i}}$ та канали передачі інформації можуть бути схильні до дії завад, а також є ненадійні елементи в пристроях для $\mathrm{K}_{\mathrm{i}}, \mathrm{S}_{\mathrm{i}}, \mathrm{D}_{\mathrm{i}}$. Функціональний опис такого підходу для підвищення достовірності паралельних ОС при реалізації процесів обробки інформації на всіх етапах систем реального часу рекомендується здійснювати в такий спосіб:

$$
\mathrm{f}_{\mathrm{i}}=\mathrm{K}_{\mathrm{i}}\left\{\begin{array}{c}
f_{i 1}\left(D_{i 1}\left(x_{i 1}^{1}, \ldots, x_{i n_{1}}\right), \ldots, D_{i 1}\left(x_{i 1}^{k_{i}}, \ldots, x_{i m_{1}}^{k_{i}}\right)\right) \\
f_{i 2}\left(D_{i 2}\left(x_{i 1}^{1}, \ldots, x_{i n_{1}}\right), \ldots, D_{i 2}\left(x_{i 1}^{k_{i}}, \ldots, x_{i m_{1}}^{k_{i}}\right)\right) \\
\ldots \\
f_{i k_{i}}\left(D_{1 k_{i}}\left(x_{i 1}^{1}, \ldots, x_{i n_{1}}\right), \ldots, D_{i k_{i}}\left(x_{i 1}^{k_{i}}, \ldots, x_{i m_{1}}^{k_{i}}\right)\right)
\end{array}\right.
$$

3 (1) маємо функціональне кодування і декодування [6], що використовують системну надлишковість. При цьому кодування відбувається одночасно з реалізацією $\left(f_{i 1}, f_{i 2}, \ldots, f_{i k_{i}}\right)$. Отримані реалізації паралельних ОС обробки при застосуванні коду Бозе-Чоудхури, а також функціонального кодування і декодування (1). Використання високоефективних кодів, що виправляють багатократні помилки, дає можливість істотно збільшити достовірність обробки інформації в паралельних ОС. Практично вже зараз використання однорідних обчислювальних середовищ (ООС), нейроподібних системних середовищ, а також високопродуктивних спецпроцесорів паралельної дії створює реальні передумови для побудови систем, що забезпечують високу достовірність обробки інформації; їx надійність, живучість при вирішенні задач попередньої обробки, розпізнаванні і класифікації складних зображень в реальному часі.

\section{4. РОЗПАРАЛЕЛЮВАННЯ АЛГОРИТМІВ ОБРОБКИ ІНФОРМАЦІЇ В ПАРАЛЕЛЬНИХ СИСТЕМАХ РЕАЛЬНОГО ЧАСУ}

Розглянемо задачі розпаралелювання обробки інформації в високопродуктивних ОС паралельної дії стосовно до систем обробки зображень. Нехай задані деякі множини обчислювальних операторів $O, O_{1}, O_{2}$ для паралельної OC-S.

Визначення 4.1. Відношенням П з $O_{1}$ в $O_{2}$ назвемо будь-яку підмножину множини $O_{1}$ х $O_{2}, \Pi \in$ $\mathrm{O}_{1} \mathrm{x} \mathrm{O}_{2}$.

Визначення 4.2. Вважатимемо, що $O_{i_{1}} \Pi O_{i_{2}}$, якщо $O_{i_{1}}$ і $O_{i_{2}}$ виконуються одночасно (паралельна обробка інформації); П(П = \|) відношення паралельності (паралельної обробки інформаціі).

Визначення 4.3. Фактор-множину множини $O$ відносно П визначимо множиною перетинів відношення П і позначимо О/П. Легко показати, що П $є$ відношенням еквівалентності. 3 цього випливає таке: 1. Кожний клас еквівалентності відповідає паралельній обробці інформації, обумовленої множиною $A$ операторів $O_{i}$, виконуваних одночасно 3 деяким оператором $O$, тобто $[O]=\left\{O_{i} / O \Pi O_{i}\right\} ;$ 2. Множина всіх класів еквівалентності по П утворює фактор-множину множини $A$ по П: $A / П ; 3$. Для фактор-множини $A / П$ існує система представників відношення П. 4. Для всіх $O_{i}$ i $O_{i_{2}} \in A$, або $\left\lfloor O_{i_{1}}\right\rfloor=\left\lfloor O_{i_{2}}\right\rfloor$ або $\left.\left\lfloor O_{i_{1}}\right\rfloor i \mid O_{i_{2}}\right\rfloor$ не перетинаються.

Таким чином, відношення еквівалентності П задане на $O$ розбиває множину $O$ на підмножини, що не перетинаються, які назвемо класами еквівалентності. При цьому для кожного а $\in O \in$ клас еквівалентності [a], що містить множину $\left\{b / a \prod b\right\}$. Множина всіх класів еквівалентності утворює фактор-множину множини $O$ по П: $O / П$.

Визначення 4.4. Одночасне виконання множини операторів $[O]=\left\{O_{i} / O \Pi O_{i}\right\}$ назвемо паралельною операцією П[0].

Легко показати, що рефлексивне і транзитивне замикання П* відношення П визначає паралельні операції

$\Pi_{\left[O_{i_{1}}^{1}\right]}, \Pi_{\left[O_{i_{2}}^{2}\right]}, \Pi_{\left[O_{i_{3}}^{3}\right]}, \ldots, \Pi_{\left[O_{i_{r}}^{r}\right]}$.

При дослідженні систем паралельної обробки інформації важливою $є$ задача розпаралелювання алгоритмів, яка включає проблеми виявлення внутрішнього паралелізму, що властивий алгоритмам. Особлива увага приділяється питанням побудови загальної теорії алгоритмів, що володіє паралельною структурою, а також одержання 
конструктивних підходів до побудови таких алгоритмів і перетворення послідовних програм в паралельні.

Використовуючи теоретико-системний підхід, розглянемо модель розпаралелювання алгоритмів. При цьому підході алгоритм обробки інформації зображається у вигляді системи
$S=\left\{X, C_{0} \tilde{Y}\right\}$, де $X$ - вхідна множина, яка визначає вхідні дані, $\tilde{Y}$ - вихідна множина, що визначає вихідні дані, $C_{0}$ - канал, в якому здійснюються перетворення. В загальному випадку

$$
X=\left\{x_{1}, \ldots, x_{n_{0}}, \tilde{Y}=\left\{\tilde{y}_{1}, \ldots, \tilde{y}_{\tilde{n}_{0}}, x_{i} \in E_{0}=\left\{e_{1}, \ldots, e_{k_{0}}, \tilde{y} \in \tilde{E}_{1}=\left\{\tilde{e}_{1}, \ldots, \tilde{e}_{\tilde{k}_{0}}, i=\overline{1, n_{0}}, j=\overline{1, \tilde{n}_{0}}, n_{0} \leq \tilde{n}_{0}, k_{0} \leq \tilde{k}_{0}, E_{0}, E_{1}\right.\right.\right.\right.
$$

- відповідно, вхідний і вихідний алфавіти букв. Канал $C_{0}$ задається в загальному випадку деякою матрицею ймовірностей $\left\|P_{i j}\right\|$,. де $P_{i j}$ ймовірність, що характеризує перетворення $x_{i}$ в $y_{i}$. Тоді система $\mathrm{S}$ представляється у вигляді підсистем виду: $\left\{X_{n_{r}}, C_{r}, \tilde{Y}_{\tilde{n}_{r}}\right.$ де $n_{r}$ і $\tilde{n}_{r}$, відповідно, потужності вхідної і вихідної множини слів. Досліджуються властивості таких систем на інформаційну взаємонезалежність i будуються паралельні розбиття П. Цей підхід дає можливість досліджувати одночасно і реалізацію алгоритму на ОС паралельної дії. Особливо цікавий такий підхід при розгляді систем машинних програм і реалізації алгоритмів у розробці пошукових систем.

При побудові ярусно-паралельної форми (ЯПФ) алгоритму важливо здійснити оцінку мінімальної кількості комірок пам'яті для реалізації алгоритму. Для цього необхідно визначити найкращий порядок реалізації підсистем. Ця задача $є$ важливою, коли задане обмеження на кількість підсистем, що є в одному ярусі ЯПФ.

При побудові спеціалізованих: процесорів таке обмеження може бути рівносильним вимозі обмеження габаритних розмірів чи архітектури OC. Ця задача $є$ особливо важливою при налаштуванні ОOC на реалізацію заданого алгоритму при магістральній або мультимагістральній обробці інформації, а також для побудови систем обробки інформації реального часу. Нехай граф $G(X, U)$ відповідає деякому процесові реалізації алгоритму. Для того, щоб вибрати порядок реалізації підсистем, необхідно топологічне впорядкувати дерево і розташувати вершини в такій послідовності, що вершина X передує вершині Y, якщо існує дуга 3 Y в А'. Таке впорядкування дерева $\mathrm{G}(\mathrm{X}, \mathrm{U})$ визначимо як послідовність $\varphi\left(x_{1}, x_{2}, \ldots, x_{n}\right)$ всіх вершин $\mathrm{G}$, таку, що для кожної дуги $\left(\mathrm{x}_{\mathrm{i}}, \mathrm{x}_{\mathrm{j}}\right) \in \mathrm{U} j<i$ має місце; дуга $\left(\mathrm{x}_{\mathrm{i}}, \mathrm{x}_{\mathrm{j}}\right)$ $\in \mathrm{U}$ називається пробігаючою над вершиною $\mathrm{x}_{\mathrm{k}}$ $\in \mathrm{U}$, якщо $j<k<i$. Ширина впорядкування графу визначається максимальною кількістю дуг $\omega_{1}$, пробігаючих над вершиною, $\mathrm{x}_{\mathrm{k}} \in \mathrm{X}$, тобто $\max \omega_{1}$ $(i=1, n)$ і позначимо через $W(\varphi)$. Тоді можна показати, що:

$$
\varphi^{\prime}\left(S_{r_{0}}\right) S_{r_{0}} \varphi^{\prime}\left(S_{r_{0}+1}\right) S_{r_{0}+1} \varphi^{\prime}\left(S_{r_{0}+2}\right) S_{r_{0}+2} \ldots \varphi^{\prime}\left(S_{n}\right) S_{n}=\varphi\left(S_{0}, S_{1}, S_{2}, \ldots, S_{n}\right)
$$

і для кожної $\varphi$ дерева $G$ iï ширина не менша ніж $v\left(S_{n}\right)$. Алгоритм визначення впорядкування мінімальної ширини $W(\varphi)$ полягає в проведенні таких етапів: 1. Побудувати ЯПФ. 2. Побудувати послідовність $\varphi$ дерева $G(S, U)$ у такий спосіб: виписуємо підряд всі підсистеми $S_{i_{1}}^{1}, S_{i_{2}}^{1}, \ldots, S_{i_{k_{1}}}^{1}$ першого ярусу, котрі інформаційно пов'язані 3 підсистемою $S_{1}^{2}$; потім виписуємо підряд всі

$$
\varphi\left(S_{i_{1}}^{1}, S_{i_{2}}^{1}, \ldots, S_{i_{k_{1}}}^{1}, S_{1}^{2}, S_{j_{1}}^{2}, S_{j_{2}}^{1}, \ldots, S_{j k_{2}}^{1}, S_{2}^{2}, \ldots, S_{S_{1}}^{1}, S_{S_{1}}^{1}, \ldots, S_{S_{k_{1}}}^{1}, S_{r_{2}}^{2}\right) .
$$

\section{3. Для одержання $\varphi$ визначаємо максимальну} кількість дуг $\omega_{l}$, пробігаючих над відповідною вершиною $S_{i} ; W(\varphi)=\max \omega_{1}$ підсистеми $S_{j_{1}}^{1}, S_{j_{2}}^{1}, \ldots, S_{j_{k_{2}}}^{1}$ першого ярусу, які інформаційно пов'язані з підсистемою $S_{2}^{2}$, і т.д., нарешті виписуємо всі підсистеми $S_{S_{1}}^{1}, S_{S_{2}}^{1}, \ldots, S_{S_{k_{1}}}^{1}$ першого ярусу, що інформаційно пов'язані 3 підсистемою $S_{r l}^{2}$. В результаті такої побудови отримаємо послідовність 


\section{5. СИНТЕЗ СКЛАДНИХ СИСТЕМ ПАРАЛЕЛЬНОЇ ОБРОБКИ ДАНИХ}

Розглянемо

ймовірності

реалізації розпаралелювання обробки інформації при з'єднанні систем в складні системи обробки інформації. Тут розглядаються синтез системи обробки інформації для проведення яруснопаралельної реалізації алгоритму, а також магістральні методи реалізації процесу обробки інформації. Цей підхід дає можливість проводити настроювання ОС, ООС в загальному випадку системних середовищ нейроподібного типу на реалізацію задачі в заданому режимі обробки інформації, що надходить. У зв'язку з цим, важливим є вибір основних операторів, що дозволяють здійснювати настроювання системи. Далі використовується системний підхід [11-14].

Нехай задана система $S_{i} \subset X_{i} \times Y_{i}$ і нехай $X_{i}=\times\left\{X_{i j}: j \in I_{x_{i}}\right\}, Y_{i}=\times\left\{Y_{i j}: j \in I_{y_{i}}\right\}$. Позначимо через $Z_{x}$ декартовий добуток компонентних множин $X_{i}$, які можуть використовуватись для реалізації з'єднань систем; а через $\mathrm{Zx}_{1}$, сімейство цих компонентних множин $\bar{X}_{i}^{*}=\left\{X_{i j}: X_{i j} \in \bar{X}_{i} \wedge X_{i j} \notin \bar{Z}_{X_{1}}\right\}$, де $\bar{X}_{i}$ сімейство компонентних множин $X_{\mathrm{i}}$; $\bar{X}_{i}^{*}=\times\left\{X_{i j}: X_{i j} \in \bar{X}_{i} \wedge X_{i j} \notin Z_{X_{1}}\right\}=\times\left\{X_{i j}: X_{i j} \in \bar{X}_{i}^{*}\right\}$.

Маємо $X_{i}=X_{i}^{*} \times Z_{X_{i}}, Y_{i}=Y_{i}^{*} \times Z_{Y_{i}}$. Множина 3'єднуваних систем визначається таким чином: $S_{i z} \subset\left(X_{i}^{*} \times Z_{X_{1}}\right) \times\left(Y_{i}^{*} \times Z_{Y_{i}}\right)$. Клас з'єднуваних систем визначимо в вигляді $\bar{S}_{z}=\left\{S_{i z}: S_{i z} \subset\left(X_{i}^{*} \times Z_{X_{i}}\right) \times\left(Y_{i}^{*} \times Z_{Y_{i}}\right)\right\}$.

У цьому класі об'єднаних систем визначені основні оператори з'єднання систем:

Каскадне З'єднання. Нехай $S_{1} \subset X_{1} \times\left(Y_{1}^{*} \times Z_{X_{1}}\right), \times S_{2} \subset\left(X_{2}^{*} \times Z_{r_{2}}\right) . \quad$ Введемо операцію "о": $\bar{S}_{Z} \times \bar{S}_{Z}$ таку, що $S_{1} \circ S_{2}=S_{3}$, де $S_{3} \subset\left(X_{1} \times X_{2}^{*}\right) \times\left(Y_{1}^{*} \times Y_{2}\right), Z_{X_{1}}=Z_{X_{2}}=Z \mathrm{i}$

$$
\left(\left(X_{1}, X_{2}\right),\left(Y_{1}, Y_{2}\right)\right) \in S_{3} \leftrightarrow(\exists Z)\left(X_{1},\left(Y_{1}, Z\right)\right) \in S_{1} \wedge\left(\left(x_{2}, Z\right), Y_{2}\right) \in S_{2} .
$$

Операцію "о" назвемо каскадним 3'єднанням або каскадною з' єднуючою операцією.

Паралельне з'єднання. Нехай $S_{1} \in\left(X_{1}^{*} \times Z_{X_{1}}\right) \times Y_{1}, S_{2} \subset\left(X_{2}^{*} \times Z_{X_{2}}\right) \times Y_{2}$. Bвe- $Z_{X_{1}}=Z_{X_{2}}=Z$ i

$$
\left(\left(X_{1}, X_{2}, Z\right),\left(Y_{1}, Y_{2}\right)\right) \in S_{3} \leftrightarrow\left(\left(X_{1}, Z\right), Y_{1}\right) \in S_{1} \wedge\left(\left(X_{2}, Z\right), Y_{2}\right) \in S_{2}
$$

Операцію "+" назвемо, паралельним з'єднанням чи паралельною об' єднуючою операцією.

Нехай $F$ - відображення; $F: \bar{S}_{Z}=\bar{S}_{Z}$ таке, що $F\left(S_{l}\right)=S_{2}$, де $S_{1} \subset\left(X^{*} \times Z_{X}\right) \times\left(Y^{*} \times Z_{Y}\right)$, а $S_{2} \subset X^{*} \times Y^{*}, Z_{X}=Z_{Y}=Z$ $(X, Y) \in S_{2} \leftrightarrow\left(\exists Z(X, Z),(Y, Z) \in S_{1}\right)$

Відображення $F$ назвемо замиканням зворотного зв'язку або операцією замикання зворотного зв'язку.

Введені три основні операції вичерпують, в основному, більшість можливих з'єднань. Нами розглянуті основні властивості введених операцій, а також досліджені ймовірності реалізації демо операцію "+": $\bar{S}_{Z} \times \bar{S}_{Z} \Rightarrow \bar{S}_{Z}$ таку, що $\mathrm{S}_{1}+\mathrm{S}_{2}=\mathrm{S}_{3}, \quad$ де $\quad S_{3} \subset\left(X_{1}^{*} \times X_{2}^{*} \times Z\right) \times\left(Y_{1} \times Y_{2}\right)$

$$
S_{1} \circ S_{2} \circ S_{3} \circ \ldots \circ S_{n}=S \subset\left(X_{1} \times X_{2}^{*} \times X_{3}^{*} \times \ldots \times X_{n}^{*}\right) \times\left(Y_{1} \times Y_{2}^{*} \times Y_{3}^{*} \times \ldots \times Y_{n-1}^{*} \times Y_{n}^{*}\right) \text {. }
$$

Тоді система $S$ припускає магістральну обробку інформації на рівнях $S_{1}, S_{2}, S_{3}, \ldots, S_{n}$. розпаралелювання обробки інформації при різноманітних операціях з'єднання систем на рівні заданих систем $[1,4,5]$.

1. Нехай задані системи обробки інформації $S_{1} \subset\left(X_{1} \times\left(Y_{1}^{*} \times Z_{X_{1}}\right)\right)$, $S_{2} \subset\left(X_{2}^{*} \times Z_{Y_{2}}\right) \times\left(Y_{2}^{*} \times Z_{X_{2}}\right)$, $S_{3} \subset\left(X_{3}^{*} \times Z_{r_{3}}\right) \times\left(Y_{3}^{*} \times Z_{X_{3}}\right)$, $\ldots, S_{n} \subset\left(X_{n}^{*} \times Z_{r_{n}}\right) \times Y_{n}$ i визначене каскадне з'єднання цих систем за допомогою каскадної 3'єднуючої операції. 
$S_{n} \subset\left(X_{n}^{*} \times Z_{X_{n}}\right)_{\text {i }} \quad$ визначене $\quad$ паралельне об’єднуючої операції

3'єднання цих систем за допомогою паралельної

$$
S_{1}+S_{2}+\ldots+S_{n}=S \subset\left(X_{1}^{*} \times X_{2}^{*} \times \ldots \times X_{n}^{*} \times Z\right) \times\left(Y_{1} \times Y_{2} \times \ldots \times Y_{n}\right) .
$$

Тоді система допускає розпаралелювання обробки інформації на рівнях $S_{1}, S_{2}, S_{3}, \ldots, S_{n}$.

3. Нехай задані системи обробки інформації $S_{1} \subset\left(X_{1}^{*} \times Z_{X_{1}}\right) \times\left(Y_{1}^{*} \times Z_{X_{1}}\right), \quad S_{2} \subset\left(X_{2}^{*} \times Z_{r_{2}}\right)$, $S_{3} \subset\left(X_{3}^{*} \times Z_{X_{3}}\right) \times Y_{3} \quad$ і визначено каскадне i паралельне з'єднання цих систем допомогою каскадної і паралельної з'єднуючої операції

$$
\left(S_{1} \circ S_{2}\right)+S_{3}=S_{12}+S_{3}=S \subset\left(X_{1}^{*} \times X_{2}^{*} \times X_{3}^{*} \times Z\right) \times\left(Y_{1} \times Y_{2} \times Y_{3}\right) .
$$

Тоді система $S$ допускає магістральну обробку інформації на рівнях $S_{1}$ і $S_{2}$ і розпаралелювання обробки інформації на рівнях $S_{12}$ та $S_{2}$.

4. Нехай задані системи обробки інформації $S_{1} \subset\left(X_{1}^{*} \times Z_{X_{1}}\right) \times Y_{1}$,

$S_{2} \subset\left(X_{2}^{*} \times Z_{X_{2}}\right) \times\left(Y_{2}^{*} \times Z_{X_{2}}\right)$,

$S_{3} \subset\left(X_{3}^{*} \times Z_{Y_{3}}\right) \times Y_{3}$ і визначене паралельне i каскадне з'єднання цих систем за допомогою паралельної і каскадної з'єднуючих операцій

$$
S_{1}+\left(S_{2} \circ S_{3}\right)=S_{1}+S_{23}=S \subset\left(X_{1}^{*} \times X_{2}^{*} \times X_{3}^{*} \times Z\right) \times\left(Y_{1} \times Y_{2}^{*} \times Y_{3}\right)
$$

Тоді система $S$ допускає магістральну обробку інформації на рівнях $S_{2}$ i $S_{3}$ і розпаралелювання обробки інформації на рівнях $S_{I}$ і $S_{23}$.

5. Нехай задані системи обробки інформації $S_{1} \subset\left(X_{1}^{*} \times Z_{X_{1}}\right) \times\left(Y_{1}^{*} \times Z_{X_{1}}\right)$
$S_{2} \subset\left(X_{2}^{*} \times Z_{X_{2}}\right) \times\left(Y_{2}^{*} \times Z_{X_{2}}\right)$,

$S_{3} \subset\left(X_{3}^{*} \times Z_{Y_{3}}^{\prime}, Z^{\prime \prime}{ }_{Y_{3}}\right) \times Y_{3}$

i визначене

паралельне і каскадне з'єднання цих систем із допомогою паралельної і каскадної з'єднуючих операцій

$$
\left(S_{1}+S_{2}\right) \circ=S_{12}+S_{3}=S \subset\left(X_{1}^{*} \times X_{2}^{*} \times X_{3}^{*} \times Z\right) \times\left(Y_{1}^{*} \times Y_{2}^{*} \times Y_{3}\right) .
$$

Тоді система $S$ допускає розпаралелювання обробки інформації на рівнях $S_{1}$ i $S_{2}$ і магістральну обробку інформації на рівнях $S_{12}$ i $S_{3}$.

6. Нехай

$S_{1} \subset\left(X_{1}^{*} \times Z_{X_{1}}\right) \times\left(Y_{1}^{*} \times Z_{Y_{1}}\right)$,

$S_{2} \subset\left(Z_{X_{2}} \times Z_{X_{2}}^{\prime} \times Z_{X_{2}}^{\prime \prime}\right) \times\left(Y_{2}^{*} \times Z_{Y_{2}}^{\prime} \times Z_{Y_{2}}^{\prime \prime}\right)$,

$, \ldots, S_{2} \subset\left(Z_{X_{n-1}} \times Z_{X_{n-1}}^{\prime} \times, Z_{X_{n-1}}^{\prime \prime}\right) \times\left(Y_{n-1}^{*} \times Z_{Y_{n-1}}^{\prime} \times Z_{Y_{n-1}}^{\prime \prime}\right)$

i визначене каскадне з'єднання, що охоплене зворотним зв'язком за допомогою каскадно з'єднуючих операцій i замикання зворотного зв'язку

$F\left(S_{1} \circ S_{2} \circ \ldots \circ S_{n}\right)=S \subset\left(X_{1}^{*} \times X_{2}^{*} \times . \times X_{n}^{*}\right) \times\left(Y_{1}^{*} \times Y_{2}^{*} \times \ldots \times Y_{n}^{*}\right)$.

Тоді система $S$ допускає розпаралелювання обробки інформації на рівнях $S_{1}, S_{2}, \ldots, S n$.

За допомогою побудованих систем можна синтезуати нові довільні за складністю системні структури. Це дає можливість ефективно провести і відповідні технічні реалізації алгоритмів, що припускають розпаралелювання i магістральну обробку інформації на заданому рівні. У такий спосіб запропонований конструк- тивний підхід настроювання (програмного або апаратного) з'єднань між окремими підсистемами на вирішення задачі чи класу задач. Для реалізації цього підходу необхідно провести функціональний опис складних систем обробки інформації, отриманих у результаті такого настроювання.

\section{6. ФУНКЦІОНАЛЬНИЙ ОПИС НАСТРОЮВАННЯ СКЛАДНИХ СИСТЕМ ОБРОБКИ ІНФОРМАЦІї}

Запропонований $\quad[1,4,5,9,10] \quad$ метод функціонального опису настроювання складних систем обробки інформації за допомогою операторів суперпозиції $S$ і рекурсії $R$. В загальному випадку отримані такі практично важливі результати:

Настроювання з'єднань між окремими підсистемами системного середовища, що реалізують функції $f_{0}, f_{1}, \ldots, f_{n}$ на проведення паралельної обробки інформації можна функціонально описати за допомогою 
термального запису $f=S^{n+1}\left(f_{0}, f_{1}, \ldots, f_{n}\right)$, де $f_{0}$ функція настроювання з'єднань.

Для заданих підсистем $S_{l}, S_{2}, \ldots, S_{n}$, які реалізують функції $f_{0}, f_{1}, \ldots, f_{n}$ і виконане настроювання з'єднань на магістральну обробку інформації, функціональний опис настроювання має термальне представлення

$$
f=\left(R\left(R\left(R\left(\ldots\left(R\left(R\left(R\left(f_{1}, f_{2}\right), f_{3}\right), f_{4}\right), f_{5}\right), \ldots, f_{n-2}\right), f_{n-1}\right), f_{n}\right)\right) .
$$

У загальному випадку, функціональний опис настроювання з'єднань підсистем на обробку інформації в системі множинний потік даних - множинний потік команд (мультимагістральна обробка інформаціï) отримуємо за допомогою термального представлення

$$
\begin{aligned}
& f=S^{n+k+1}\left(f_{0}, f_{1}, \ldots, f_{k}, R\left(R\left(\ldots\left(R\left(R\left(f_{1}^{1}, f_{2}^{1}\right), f_{3}^{1}\right), f_{n}^{1}\right), \ldots, f_{m_{1}-1}^{1}\right) f_{m_{1}}^{1}\right)\right), \ldots \\
& R\left(R\left(\ldots\left(R\left(R\left(f_{1}^{n}, f_{2}^{n}\right), f_{3}^{n}\right), f_{n}^{n}\right), \ldots, f_{m_{n}-1}^{n}\right) f_{m_{n}}^{n}\right)
\end{aligned}
$$

3 останнього випливає ряд практично важливих випадків систем мультимагістральної обробки інформації. При цьому є можливість будувати як завгодно складні ієрархічні системні середовища.
У загальному випадку настроювання з'єднань на узагальнену мультимагістральну обробку інформації функціональний опис має термальне представлення

$$
f=R\left(R\left(\ldots R\left(R\left(\begin{array}{c}
S^{n_{1}+1}\left(f_{0}^{1}, f_{1}^{1}, \ldots, f_{n_{1}}^{1}\right) \\
S^{n_{2}+1}\left(f_{0}^{2}, f_{1}^{2}, \ldots, f_{n_{2}}^{2}\right)
\end{array}\right), \ldots, S^{n_{k_{1}}+1}\left(f_{0}^{k-1}, f_{1}^{k-1}, f_{2}^{k-1}, \ldots, f_{n_{k-1}}^{k-1}\right)\right), S^{n_{k}+1}\left(f_{0}^{k}, f_{1}^{k}, f_{2}^{k}, \ldots, f_{n_{k}}^{k}\right)\right)\right)
$$

Цей функціональний опис враховує всі можливі інформаційні зв'язки між підсистемами. В останньому випадку маємо ряд практично важливих окремих випадків. Використовуючи цей функціональний опис можна провести настроювання системи на реалізацію обчислювальних процесів, що довільно галузяться.

Ці системи відбивають концепцію ієрархічного i глибокого розпаралелювання алгоритмів на різних рівнях, 3 допомогою яких можна легко реалізувати будь-які "ланцюгові" розгалужені фізичні процеси, процеси опису, розпізнавання i класифікації складних зображень, а також прийняття i видачі відповідних керуючих дій.

Функціональний опис дозволив досліджувати задачу синтезу автоматів $S_{a i}=\left(\tilde{C}_{i}, X_{i}, Y_{i}, \lambda_{i}, \tilde{a}_{1 i}\right)$ за допомогою операцій паралельного і каскадного з'єднання і замикання зворотного зв'язку. При цьому розглянуті задачі розпаралелювання і функціонального опису настроювання при з'єднанні автоматів у мережі, які реалізують паралельну і магістральну обробку інформації.

\section{ВИСНОВКИ}

Проведені дослідження дозволяють сформулювати такі основні перспективні наукові напрямки та розробки.

1. Методи і принципи синтезу систем реального часу, що забезпечують високу продуктивність обробки великої кількості інформації, що швидко надходить, i достовірність одержання результату для видачі керуючих дій, а також високі показники інформаційної ефективності, надійності, точності, живучості і готовності систем.

2. Побудова основ загальної теорії алгоритмів і систем, що мають паралельну структуру, а також одержання конструктивних підходів до побудови таких алгоритмів і систем 3 урахуванням їх фізичної i обчислювальної реалізації.

3. Концепція ієрархічності i глибокого розпаралелювання алгоритмів на різних рівнях при синтезі складних систем обробки великої кількості інформації що швидко надходить; синтез системних середовищ, нейроподібних i систолічних структур.

4. Методи й алгоритми розпаралелювання обробки інформації що швидко надходить; побудова класу алгоритмів, які допускають розпаралелювання на заданому рівні i високопродуктивне опрацювання інформації. 
5. Принцип ієрархічності структури складних зображень i глибокого розпаралелювання обробки інформації на заданому рівні при сприйнятті, опису, попередній обробці, розпізнаванні складних зображень; концепції взаємооднозначної відповідності множини алгоритмів структурного розпізнавання складних зображень, множині паралельних операцій; реалізація паралельних алгоритмів 3 допомогою високопродуктивних спецпроцесорів паралельної дії, проблемноорієнтованих систем, системних середовищ, нейроподібних і систолічних структур.

\section{ЛITEPATУРА}

1. Параллельная обработка информации: в 5-ти т. - Т. 1. Распараллеливание алгоритмов обработки информации / А.В.Бабичев, В.А.Вальковский, В.В.Грицык и др./ Под ред. А.Н.Свенсона. - Киев: Наукова думка, 1985. $280 \mathrm{c}$.

2. Параллельная обработка информации: в 5-ти т. - Т.2: Параллельные методы и средства распознавания образов / П.А.Бакут, З.Ф.Бабуров, А.М.Варфоломеев и др./ Под ред. В.В.Грицыка. - Киев: Наукова думка, 1985.- 280 с.

3. Параллельная обработка информации: в 5-ти т. - Т.5: Проблемно-ориентированные и специализированные средства обработки информации / А.И.Аксенов, В.В.Аристов, Е.Ю.Барзилович и др. / Под ред. В.В.Грицыка и Б.Н.Малиновского. - Киев: Наукова думка, 1990. -504c.

4. Грицык В.В., Сулицкий Ю.Н. Распараллеливание и настройка в сложных системах параллельной обработки информации. Львов, 1981. 48 с.(ФМИ АН УССР. Препринт N 60).

5. Грицык В.В. Распараллеливание алгоритмов обработки информации. - Киев: Наукова думка, 1981.

6. Виноград С. Коеэн Дж. Надежные вычисления при наличии шумов. - Москва: Наука, 1968.

7. Манна 3. Теория неподвижной точки программ // Кибернетический сборник. - 1978. - Вып.15.

8. Грицык В.В., Михайловский В.М. Оценка качества передачи информации. - Киев: Наукова думка, 1973.

9. Мальцев А.И. Алгоритмы и рекурсивные функции. - М.: Наука, 1965.

10. Роджерс X. Теория рекурсивных функции и эффективная вычислимость. - М.: Мир, 1972.

11. Параллельная обработка информации: в 5-ти т. - Т.3: Вычислительные системы, структуры и среды для решения задач большой размерности / МЛ.Бартиш, М.П.Богачев, М.А.Глазков и др./ Под ред. В.В.Грицыка. - Киев: Наукова думка. $1986,-288 \mathrm{c}$.

12. Месарович М, Такахари Я. Общая теория систем: математические основы. - М.: Мир, 1978.
13. Месарович М., Мако Д., Такахари Я. Теория иерархических многоуровневых систем. - М.: Мир, 1973.

14. Параллельная обработка информации: в 5-ти т. - Т.4. Высокопроизводительные системы параллельной обработки информации / Л.Б.Авгуль, А.И.Белоус, А.И.Гречишников и др. / Под ред. В.В.Грицыка. - Киев: Наукова думка, 1988.- 272 с.

15. Грицик В.В., Березький О.М., Березька К.М. Метод опису та синтезу зображень-орнаментів. Доповіді Національної академії наук України. 2002. №7. - C. 64-71

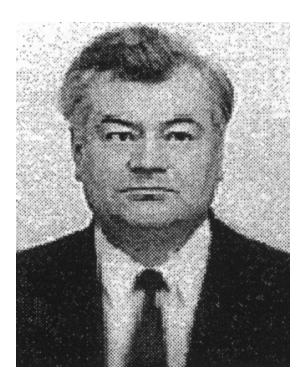

Володимир

Грицик народився в 1941 році. Закінчив фракультет механіки та математики Львівського державного університету. Отримав ступінь кандидата фозико-математичних наук в 1971 році і ступінь доктора технічних наук. $\epsilon$ профресором з 1986 року. $€$ членом кореспондентом НАН України з 1991 року. Працює директором інституту інформаційної інфраструктури НАН України та міністерства інформації України. Є головою секції інформатики Західного наукового центру НАH України та Міністерства науки i технологій України. Завідувач кафедри Соціальної інформатики в національному університеті "Львівська політехніка". Головний редактор журналу Інормаційні технології і системи.

Наукові інтереси: використання інформації та технологій нейронних мереж для вирішення комплексу промислових, технологічних та екологічних проблем; високопродуктивні системи обробки інформації в реальному часі; застосування комп'ютерів та математичних методів і моделей в науці. Автор 10 монографрій та понад 300 сmameй.

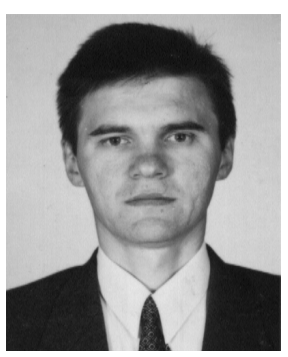

Олег Березький народився в 1962 році. Закінчив фракультет автоматики Львівського політехнічного інституту в 1985 році. Доцент кафредри інформаційно-обчислювальних систем і управління Тернопільської академії народного господарства.

Кандидат технічних наук з 1996 року.

Наукові інтереси: інтелектуалізація інформаційно-вимірювальних та обчислювальних систем, математичне моделювання, нові інфрормаційні технології. Автор 60 наукових праць та винаходів. 